ACRL PHILADELPHIA CHAPTER ANNUAL MEETING

Approximately one hundred twenty librarians met at the Samuel Paley library of Temple University, Philadelphia, on May 13, for the annual meeting of the Association of College and Research Libraries, Philadelphia Chapter.

The morning session was opened by a welcome from Warren S. Owens, director of libraries, Temple University. A brief business meeting followed, presided over by Clyde Haselden, president. Ethel Klingerman, secretary-treasurer, read the minutes of the last annual meeting and the treasurer's report.

Mr. Haselden reported that twenty-five signatures of ACRL members were necessary to establish the Chapter under the revised ACRL Constitution and Bylaws (ACRL News, no. 7, October, 1966, p.134-136). As a result of this announcement, twenty-eight ACRL members signed a petition requesting this establishment of the Philadelphia Chapter, and it was sent to George M. Bailey, executive secretary of ACRL. The new officers and members of the Board of Directors, 1967-68, are Vice President (and President-Elect): Richard Snyder; Secretary-Treasurer: JOAN GoTwals; Director-atLarge: EMEry W. WVinisish, Jr.

Miss Klingerman stated that the Executive Board had fulfilled the May 14, 1966 recommendation of membership and increased the Chapter's annual contribution to the Union Catalog of Pennsylvania from $\$ 50$ to $\$ 100$. The business meeting was then adjourned.

The morning program on Reclassification to the Library of Congress System was presided over by Herbert Anstaett, librarian of Franklin and Marshall College and the program chairman. He introduced Mrs. Irene Rice, reclassification director of Franklin and Marshall. Mrs. Rice spoke of the organization and operation of the LC Reclassification Project at the College.

Next Mr. Anstaett introduced members of the panel on reclassification: Mrs. Miriam Weiss (Beaver College), Jack Slater (Drexel), Geraldine McCulley (Lippincott library, UPA), Alice Hall (Lafayette), and Lee Brown (PMC).

Both Mrs. Weiss and Mr. Slater described the reclassification project at their colleges, and Miss McCulley indicated the plans for reclassification at the Lippincott library. Miss Hall gave the results of a questionnaire sent to ten college and university libraries in the process of reclassifying to LC. Mr. Brown spoke against reclassification to $\mathrm{LC}$.

After the panel had finished, there was a brief question period and the meeting was adjourned for lunch and an informal tour of the new Samuel Paley library building.
The Area College Library Cooperative Program, South Central Pennsylvania was the topic for the afternoon program session. Mrs. Lillian H. Smoke, librarian of Gettysburg College was the speaker. She described fully the origin, growth, and advantages of the cooperative program adopted by nine south central Pennsylvania colleges and the Pennsylvania state library in 1965. Questions and some discussion concluded the program for this session.

Mr. Haselden expressed the group's appreciation to Mr. Anstaett and the participants for two excellent programs. Mr. Haselden then presented Warren S. Owens as the new president of the Chapter, and the meeting was adjourned.-Clyde L. Haselden.

\section{NON-WESTERN COLLECTIONS}

Library resources of ninety-six state colleges and universities offering non-Western courses vary from 20,000 to 465,000 volumes, with an average of about 129,000, and annual additions of books and periodicals that relate to non-Western studies amount to 6.3 per cent and 4.2 per cent respectively of current total annual acquisitions, according to a recently published study. Of 132 colleges that answered an inquiry from the Association of State Colleges and Universities, only about onethird responded to a question concerning planned expenditures for developing nonWestern holdings of the library; colleges that answered will average just under 8 per cent a year for the next three years, according to the association's report of the survey.

To the request for colleges to evaluate their holdings as good, adequate, or poor, seventeen of the ninety-six rated their libraries as good, forty-five as adequate, and twenty-one as poor, for instruction. For faculty research, only two colleges rated their libraries as good, and sixty-eight rated them poor.

Institutions which considered their library holdings less than adequate for their present non-Western courses responded in various ways to a request to list their three greatest needs. The majority listed their needs in terms of additional publications in each of three geographic areas, with Africa, Asia in general, and the Slavic and East European area being the most frequently mentioned. A smaller number of colleges expressed their needs in other than geographic terms and included such things as additional funds for more space, more bibliographic specialists, more clerical help, out-ofprint books, foreign documents, monographs and, more frequently than any other one need, more periodicals, according to International Education in the Developing State Colleges and Universities, a report of a study conducted for the ASCU dated November 1966, by Fred F. Harcleroad and Alfred Kilmartin. 